\title{
Optimization of Jakwir Cetem Services to Increase Public Private Partnerships in the New Normal Era in Tegal Bahari City
}

\author{
Hapsari Kharisma Maharani*, Dian Maysaroh, Nita Nurliawati, Aghisni Ramadhani, Klara Muji Rahayu \\ Public Administration \\ Polytechnic STIA LAN Bandung \\ Bandung, Indonesia \\ *hapsari.maharaniasa@gmail.com
}

\begin{abstract}
Public Private Partnership (PPP / P3s) is a collaboration that aims to overcome the limited capabilities the government and the private sector in implementing services and achieving innovation for regional development. Facing the era of adaptation to new habits (new normal), the government is required to transform following the development of public services in order to be able to overcome the more complex public problems. The implementation of partnerships that lead to public services is evidenced by the existence of the Jakwir Cetem or Aja Kosi Wira Wiri, cepat, tepat, melayani. It means the customer does not need to go anywhere and the required documents will be free delivered by Grab express to the address they put on the application. This partnership is oriented towards the principles of good governance which is now a global trend in the general model of government. Thus, the focus of the partnership pattern from the Jakwir Cetem Population and Civil Registration Agency Tegal City's application service is expected to be a reference for other local government innovations so that it is more eager and faster in making changes. The research method used is a descriptive method with a qualitative approach, where the locus is through the partnership service application of the Jakwir Cetem using several data collection techniques, such as: interviews and surveys.
\end{abstract}

Keywords-public privat partnership, inovation, new normal era, public services

\section{INTRODUCTION}

The Corona-19 virus pandemic has spread throughout the world without exception to Indonesia since the beginning of 2020 which has had a significant impact on all aspects. One policy after another is made in order to solve public problems that are increasingly complex due to the current uncertain situation. The government as a facilitator has an important obligation to meet every need of the community through public services even in the midst of the ongoing virus. The existing service process must be able to uphold professional values, the quality-of-service products must be maintained, and the costs and completion times are in accordance with the standards [1]
One important aspect of public service is population administration. Even though social life has almost stopped due to the pandemic that has occurred, but people still need their right to obtain the demographic information they need, such as birth / death certificates, Identity Card, Family Card, Child Information Card, and so on. In addition, population administration is beneficial for the (central) government and local governments for planning development programs as a foundation for improving and developing the quality of the population itself [2]. Thus, this affair becomes a strategic task of the government which covers all levels of society throughout its life. The output received by the community is in the form of population administration documents as a means of self-identification and an intermediary to obtain other services such as health, education, and other access they need. The ownership of an ID allows eligible bearers benefit from public services provided by the government [3].

Tegal city received the 3rd largest predicate in Central Java based on the population census in June 2020 with a population of 142,105 people. The consequence of the rapid population rate of Tegal City is the increasing number of public services that must be provided by the local government. In the midst of this ongoing pandemic, the city is viral due to a massive lockdown for the first time in Indonesia that makes it difficult for people to access their rights, because there are restrictions that need to be done such as reducing the number of visitors, closing traffic access, large-scale social restrictions, the stay-athome requirement, and the Work from Home policy for bureaucrats. This has an impact on decreasing the quality of public services in Tegal City itself. To anticipate this phenomenon, Population and Civil Registration Agency of Tegal City as an authorized institution makes efforts to facilitate the public in accessing population administration services.

An interesting innovation came from Jakwir Cetem or Aja Kosih Wira Wiri, Cepat dan Tepat Melayani by the Tegal City Population and Civil Registration Agency. This is inspired by the interesting features of the online taxi service, such as 
ordering food and delivering packages online. This service is an application that can be downloaded on the Google Playstore on your mobile. Uniquely, this service collaborates with the Grabexpress company for document delivery. In the midst of the limitations that occur, it is easy for people to get their rights as citizens. Customers only need to enter the desired request and the documents will be sent free of charge because all costs are borne by the APBD. In addition, they can also update their personal data independently and it will be checked for legality by authorized officers. According to the author's observations, so far there have been no obstacles felt by the two partnerships. They feel satisfied and mutually benefited from this service. It is proven that on the first day of launching this service, the Population and Civil Registration Agency registered its name at the Indonesian World Records Museum (MURI) by delivering 500 population documents and involving 485 Grab drivers. However, this system is not perfect because it is not directly integrated with the Grab Express company, so it needs better maintenance.

The scope of this research covers aspects of the partnership model between The Population and Civil Registration Agency of Tegal City and The Grab Company in the context of a Public Private Partnership, and how to optimize the use of this application as an innovative solution to public service problems in the current new normal era.

\section{METHODS}

The research method used in this research is the descriptive method through a qualitative approach based on written, oral, or visual documentation through online media. The analysis used in this study is based on the results of the analysis of news, websites, articles, and journals related to the optimization of public service partnerships in the Jakwir Cetem Application service of the Tegal City Office of Population and Civil Registration Agency. Besides, we used the in-depth interview technique as a data collection method supported by a questionnaire survey of respondents which was conducted first to the people of Tegal City. Even though it has just been implemented, during the survey we encountered obstacles because the digital literacy of the people of Tegal City was still low, so it was rather difficult to find responsive respondents.

The location of the research we have done is at the Tegal City by interviewing the Population and Civil Registration Agency as service provider and the Grab company for the Jakwir Cetem application service. Also, we used a survey questionnaire method to respond to community satisfaction with the services provided by the Tegal City Population and Civil Registration Agency. Service as well as the success of the Jakwir Cetem application service system using the DeLone and McLean theory models.

\section{RESULTS}

The research study formulates 2 variables that can determine the results of partnerships from public services at the Tegal City Population and Civil Registration Agency in collaboration with Grab Company to create new service products, namely the Jakwir Cetem Application with various variables, namely analysis, and interview system. The success analysis used DeLone and McLean's theory.

\section{A. DeLone and McLean Model to Support Optimization of Cetem Jakwir Service System in Tegal City Population and Civil Registration Service}

Systems supported by Information Technology provide added value to an organization if they are designed to be effective and efficient information. It is difficult to measure and judge the quality of effective information systems. This has prompted many researchers to develop models for assessing the success of a system. William H. DeLone and Ephraim R. McLean in 1981-1987 [4] conducted a study to create a model that explains what dimensions affect an outcome of an information system. In this model, they propose 6 dimensions that affect the success of an information system. After the model was published, many researchers tried to validate the model to various types of systems with different contexts, one of which was Seddon and Kiew [5]. They say that users should be separated from the utility, and even if a system is widely used, it does not mean it is "useful". Also, many other researchers argue with each other and change this model, because in 2003 William H. DeLone and Ephraim R. McLean again researched to update the model.

To assess the information system issued by the Department of Population and Civil Registration (Disdukcapil) through the Jakwir Cetem application, we use the DeLone and McLean models which have 6 evaluation variables, namely: information quality, system quality, service quality, usage, user satisfaction, and net benefits. This model is used to measure the success of implementing the Jakwir Cetem application at the Office of Population and Civil Registration Agency (Disdukcapil) of Tegal City. Besides, with this model, we can find out the factors that affect the success and failure of the implementation of Jakwir Cetem so that it can be evaluated for further development and refinement. We used the DeLone and McLean models as material for questionnaires related to Jakwir Services and Use of the Cetem Application which were distributed throughout the City of Tegal as material for our study of the phenomenon of the problems raised. These DeLone and McLean models are shown in the following figure 1 .

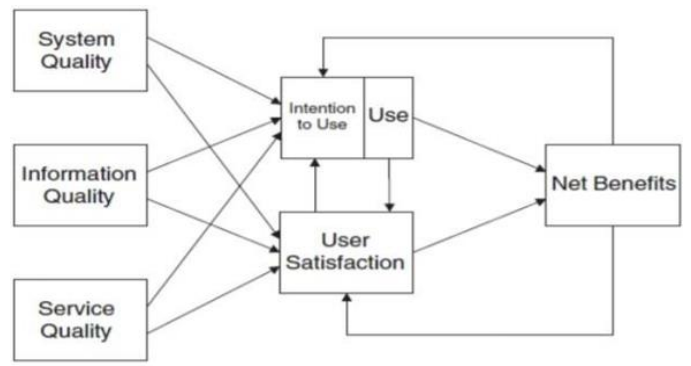

Fig. 1. DeLone and McLean's theory model. 
Based on the model image shown, it is considered suitable and usable because it has been widely used by previous Indonesian researchers to measure the success of the system. This model is a reference in developing a questionnaire to measure the success of the implementation of Jakwir Cetem at the Tegal City Population and Civil Registration Agency.

\section{B. Variables and Indicators}

The variables used are in accordance with the existing hypotheses in the DeLone and McLean models, which then search for indicators that affect these variables. The indicators obtained have been proven by previous researchers, including:

1) Quality of information: The quality of this information measures the quality of the output of the information system issued. This is measured subjectively by the user, hereinafter referred to as the perceived quality of information. J. Livari [6] uses 6 measurement scales, namely: completeness, precision, reliability, always updated data (currency), and output form (output format).

2) System quality: System quality is system performance which refers to how well the hardware, software, policies, and information system procedures can provide information about user needs. This is used to measure the quality of the information system itself, both software and hardware. The indicators used in J. Livari's study consisted of 6 measurement scales, namely: system flexibility, system integration, response time, error recovery, ease of access, and language [6].

3) Quality of service: Service quality is a comparison between customer expectations and the perceived real service received. According to DeLone and McLean [7], three components affect service quality, that is assurance, namely quality assurance provided by the system, empathy (empathy system) about the system's concern for users, responsiveness (system responsiveness), regarding the quality of the system in response to actions done by the user.

4) Use: Usage includes the use of output (information use) and use of the system (system use). From these differences that in the context of the use of the Jakwir Cetem information system, the intended use is the use of the application or information system from the system itself (system use). Looking at J. Livari's research [6], this essay uses two items, namely the use of daily time (daily used time) and frequency of use, that is the frequency of system usage during work.

5) User satisfaction: System user satisfaction is the responses and responses given by users after using the information system. User attitudes toward information systems are subjective criteria regarding how much users like the system used. Adopting the DeLone and McLean [7] model, this essay uses two items, namely:

a) Information satisfaction (repeat purchase): Information satisfaction is the difference between the information required and the information received. Information satisfaction is the result of a comparison between the needs or expectations of information systems and the performance of the received system.

b) Complete satisfaction (repeat visit): One of the forms of global satisfaction with all the systems that have been presented and the interactions made is regarding the level of satisfaction of services and information systems. As well as the benefits in the process of input and output received

6) Net benefits: The net benefits obtained can also be felt by individuals and organizations after implementing information systems. The indicators used are the speed of completing tasks, work performance, effectiveness, ease of work, and usability at work.

7) Questionnaire preparation: Regarding the variables and indicators of the DeLone and McLean models previously described, a series of questionnaires was obtained based on the indicators obtained from previous research. The variables of information quality (IQ), system quality (SQ), service quality (SEQ), usage (U), user satisfaction (US), net benefits (NB). The components of the questionnaire can be seen in the following table 1 :

TABLE I. COMPONENTS OF THE QUESTIONNAIRE

\begin{tabular}{|c|c|c|}
\hline Component & Indicator & Questionnaire \\
\hline \multirow{4}{*}{$\begin{array}{l}\text { Information Quality } \\
\text { [6] }\end{array}$} & $\begin{array}{l}\text { Completeness } \\
\text { (IQ1) }\end{array}$ & $\begin{array}{l}\text { I got complete data according } \\
\text { to job requirements; }\end{array}$ \\
\hline & Reability (IQ3) & $\begin{array}{l}\text { I can rely on the data } \\
\text { obtained to meet my } \\
\text { information needs; }\end{array}$ \\
\hline & Currency (IQ4) & $\begin{array}{l}\text { The data obtained is the latest } \\
\text { information and is always } \\
\text { updated; }\end{array}$ \\
\hline & $\begin{array}{l}\text { Format of Output } \\
\text { (IQ5) }\end{array}$ & $\begin{array}{l}\text { The available data can be } \\
\text { used in other tools or media. }\end{array}$ \\
\hline \multirow{6}{*}{ Quality System [6] } & $\begin{array}{l}\text { System Flexibility } \\
\text { (SQ1) }\end{array}$ & $\begin{array}{l}\text { I can use the system and } \\
\text { change the available data } \\
\text { according to } \\
\text { requirements; }\end{array}$ \\
\hline & $\begin{array}{l}\text { System Integration } \\
\text { (SQ2) }\end{array}$ & $\begin{array}{l}\text { I can interact with other } \\
\text { systems and agencies using } \\
\text { the existing system; }\end{array}$ \\
\hline & $\begin{array}{l}\text { Time to Respond } \\
\text { (SQ3) }\end{array}$ & $\begin{array}{l}\text { I don't need long time to get } \\
\text { information after } \\
\text { accessing the system; }\end{array}$ \\
\hline & $\begin{array}{ll}\text { Error } & \text { Recovery } \\
\text { (SQ4) } & \end{array}$ & $\begin{array}{l}\text { The system provides repair } \\
\text { facilities in case of system } \\
\text { failure; }\end{array}$ \\
\hline & $\begin{array}{l}\text { Convinience } \\
\text { Access (SQ5) }\end{array}$ & $\begin{array}{l}\text { I feel comfortable and easy to } \\
\text { use the system; }\end{array}$ \\
\hline & Language (SQ6) & $\begin{array}{l}\text { I can easily understand the } \\
\text { language that sisem means }\end{array}$ \\
\hline \multirow[t]{3}{*}{ Service Quality [7] } & Assurance (SEQ1) & $\begin{array}{l}\text { I feel safe in accessing or } \\
\text { sending data through the } \\
\text { system; }\end{array}$ \\
\hline & Empath y (SEQ2) & $\begin{array}{l}\text { The system provides some } \\
\text { input that might be useful; }\end{array}$ \\
\hline & $\begin{array}{l}\text { Responsiveness } \\
\text { (SEQ3) }\end{array}$ & $\begin{array}{l}\text { The system responds according } \\
\text { to what I do. }\end{array}$ \\
\hline
\end{tabular}


Table 1. Cont.

\begin{tabular}{|c|c|c|}
\hline Component & Indicator & Questionnaire \\
\hline \multirow[t]{2}{*}{ Use [6] } & \begin{tabular}{|lll}
$\begin{array}{l}\text { Daily } \\
\text { (U1) }\end{array}$ & Used & Time \\
\end{tabular} & $\begin{array}{l}\text { Within a day I access the } \\
\text { system; }\end{array}$ \\
\hline & $\begin{array}{l}\text { Frequency of Use } \\
\text { (U2) }\end{array}$ & $\begin{array}{l}\text { While working in the agency, } \\
\text { the frequency with which I } \\
\text { accessed the system. }\end{array}$ \\
\hline \multirow[t]{3}{*}{$\begin{array}{l}\text { User } \\
{[7]}\end{array}$} & \begin{tabular}{|l|}
$\begin{array}{l}\text { Repeat } \\
\text { (US1) }\end{array}$ \\
\end{tabular} & $\begin{array}{l}\text { I am satisfied with the data } \\
\text { and information obtained; }\end{array}$ \\
\hline & 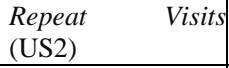 & $\begin{array}{l}\text { I am satisfied with the } \\
\text { available system; }\end{array}$ \\
\hline & $\begin{array}{lr}\text { Speed } & \text { of } \\
\text { Acomplishing } & \text { task } \\
(\mathrm{NB} 1) & \\
\end{array}$ & $\begin{array}{l}\text { I can get work done faster } \\
\text { using the system; }\end{array}$ \\
\hline \multirow[t]{4}{*}{ Net benefit [8] } & $\begin{array}{l}\text { Job Performance } \\
\text { (NB2) }\end{array}$ & $\begin{array}{l}\text { My performance is better with } \\
\text { the system; }\end{array}$ \\
\hline & $\begin{array}{l}\text { Effectiveness } \\
\text { (NB3) }\end{array}$ & $\begin{array}{l}\text { I am more effective at working } \\
\text { with systems; }\end{array}$ \\
\hline & Ease of Job (NB4) & $\begin{array}{l}\text { I find it easier to work with the } \\
\text { system; }\end{array}$ \\
\hline & $\begin{array}{l}\text { Usefullness in work } \\
\text { (NB5) }\end{array}$ & $\begin{array}{l}\text { The system is very useful } \\
\text { in completing work } \\
\text { and organizational activities. }\end{array}$ \\
\hline
\end{tabular}

\section{DISCUSSION}

\section{A. Interview Results the Population and Civil Registration Agency of Tegal City and the Grab Company}

One of the results of the analysis of this research is the data collection method, namely in-depth interviews with the Tegal City Population and Civil Registration Agency and the Grab Company. These are the data we got from in-depth interviews (table 2 and table 3 ):

\section{TABLE II. RESUlt OF INTERVIEW WITH TEGal City POPULATION} AND CIVIL REgistration Agency SERVICE OfFICERS

\begin{tabular}{|c|c|}
\hline $\begin{array}{l}\text { In your opinion, how } \\
\text { important are public services, } \\
\text { especially services from Grab } \\
\text { itself, during the Pandemic } \\
\text { Period? }\end{array}$ & $\begin{array}{l}\text { Public services must be optimal no matter what the } \\
\text { conditions are. In Pandemic, the Grab Company wants } \\
\text { to help the government with digitization, therefore we } \\
\text { decided to partner in document delivery, } \\
\text { especially in the Jakwir Cetem application service in } \\
\text { Tegal City. }\end{array}$ \\
\hline $\begin{array}{l}\text { Regarding the Grab express } \\
\text { partnership program with the } \\
\text { Population and Civil } \\
\text { Registration Agency through } \\
\text { Jakwir Cetem, do you think } \\
\text { it has been effective? }\end{array}$ & $\begin{array}{l}\text { Yes, we has. This partnership program is one of the } \\
\text { steps taken to support the City of Tegal to go digital. } \\
\text { Certainly by clear transparency and ease of service for } \\
\text { those who initially had to queue at the Population and } \\
\text { Civil Registration Agency. }\end{array}$ \\
\hline $\begin{array}{l}\text { What are the obstacles faced } \\
\text { by Grab express partners } \\
\text { during the Pandemic? }\end{array}$ & $\begin{array}{l}\text { The obstacle faced by Grab express partner so far is } \\
\text { the lack of an internet network, which causes the } \\
\text { portal to often crash. Then, in terms of document } \\
\text { delivery, maps or locations sometimes do not match } \\
\text { the point but will be adjusted immediately. }\end{array}$ \\
\hline $\begin{array}{l}\text { How did it start when Jakwir } \\
\text { Cetem decided to partner with } \\
\text { Grab Express and collaborate } \\
\text { as an alternative solution? }\end{array}$ & $\begin{array}{l}\text { Initially, it was from Grab's desire to help the } \\
\text { government and society in overcoming public } \\
\text { problems }\end{array}$ \\
\hline $\begin{array}{l}\text { How is the concept of grab } \\
\text { express partnership with } \\
\text { Population and Civil } \\
\text { Registration in overcoming } \\
\text { barriers to public services } \\
\text { during the Pandemic period to } \\
\text { the present? }\end{array}$ & $\begin{array}{l}\text { The concept used is the collaboration of delivery and } \\
\text { the City Government of Tegal to cover all costs } \\
\text { needed for operations. }\end{array}$ \\
\hline $\begin{array}{l}\text { How do Tegal people respond } \\
\text { to the implementation of } \\
\text { Jakwir Cetem? }\end{array}$ & $\begin{array}{l}\text { Segmented from educational or community } \\
\text { backgrounds, respondents are not technology-savvy } \\
\text { which has an impact on the revolutionary shift in } \\
\text { public services. Along with understanding, the easier }\end{array}$ \\
\hline
\end{tabular}

\begin{tabular}{|c|c|}
\hline & $\begin{array}{l}\text { it is to understand service technology. For millennials } \\
\text { with high school education and above, the response is } \\
\text { good. For example, Tegal city people who live in } \\
\text { Jakarta can easily reprint their KTPs, make a transfer } \\
\text { letter with an officially signed power point. }\end{array}$ \\
\hline $\begin{array}{l}\text { What are the challenges faced } \\
\text { by Population and Civil } \\
\text { Registration Agency in } \\
\text { providing services through the } \\
\text { Jakwir Cetem } \\
\text { application? }\end{array}$ & $\begin{array}{l}\text { The first challenge is how to know the validity of } \\
\text { the document/data. it means there must be the } \\
\text { development of a filtering system, using authenticity } \\
\text { detection algorithms because there is no authority } \\
\text { for material testing. Second, how can the Jakwir Cetem } \\
\text { application system be integrated in real-time with the } \\
\text { Grab Driver and are included in the application feature } \\
\text { so we have to coordinate with the grab center office in } \\
\text { Singapore. Third, how this system will run on many } \\
\text { platforms in the future, because this is only on } \\
\text { Android, not on iOS. Fourth, with the prediction that } \\
\text { humans will be lazy to type one day, so that this } \\
\text { feature can be upgraded via voice notes. It is hoped } \\
\text { that by } 2025 \text { the Jakwir Cetem system will go } \\
\text { national. }\end{array}$ \\
\hline $\begin{array}{l}\text { What is the partnership pattern } \\
\text { between Population and Civil } \\
\text { Registration Agency and } \\
\text { Grab? }\end{array}$ & $\begin{array}{l}\text { Jakwir Cetem partnership partnership pattern is g2b, } \\
\text { government to business. }\end{array}$ \\
\hline $\begin{array}{l}\text { How did Jakwir Cetem get so } \\
\text { many awards? }\end{array}$ & $\begin{array}{l}\text { This is inseparable from the intervention of regional } \\
\text { heads who want to revolutionize them with the MURI } \\
\text { record award in October } 2018 \text {, top provincial level } \\
\text { innovation, and top digital award. }\end{array}$ \\
\hline $\begin{array}{l}\text { In your opinion, can the } \\
\text { achievements of the previous } \\
\text { questions be called exemplary } \\
\text { alternative solutions in the } \\
\text { realm of public services for } \\
\text { other regions? }\end{array}$ & $\begin{array}{l}\text { It is possible with replication but requires data } \\
\text { collection and fixing problems, eg connection and } \\
\text { perfection approaches. }\end{array}$ \\
\hline $\begin{array}{l}\text { What interesting things made } \\
\text { the Tegal City Population } \\
\text { and Civil Registration } \\
\text { Agency finally choose Grab } \\
\text { Express to partner with? }\end{array}$ & $\begin{array}{l}\text { It was decided to partner with Grab because initially } \\
\text { discussions with the mayor wanted another provider, } \\
\text { but they did not yet have ITE integration services and } \\
\text { the procedure was difficult. Finally it was decided to } \\
\text { bring it through an agreement with its developer. }\end{array}$ \\
\hline $\begin{array}{l}\text { After this, does the Population } \\
\text { and Civil Registration Agency } \\
\text { intend to establish private } \\
\text { partnerships in services to } \\
\text { reach the public more easily } \\
\text { and accurately? }\end{array}$ & $\begin{array}{l}\text { Of course, especially the child's identity card to } \\
\text { facilitate service. }\end{array}$ \\
\hline $\begin{array}{l}\text { How is the benefit of the } \\
\text { Jakwir Cetem application for } \\
\text { the community? }\end{array}$ & $\begin{array}{l}\text { Facilitate people's civil rights, especially in the midst } \\
\text { of a pandemic. }\end{array}$ \\
\hline $\begin{array}{l}\text { What are the risks associated } \\
\text { with implementing the Jakwir } \\
\text { Cetem? }\end{array}$ & $\begin{array}{l}\text { First, the problem of data security because the system } \\
\text { is not fully developed. Second, the problem of } \\
\text { document falsification and validation of supporting } \\
\text { data. }\end{array}$ \\
\hline $\begin{array}{l}\text { How do budgets } \\
\text { before compare } \\
\text { implementation? }\end{array}$ & $\begin{array}{l}\text { Regarding Law } 24 \text { of } 2013 \text {, when there was a digital } \\
\text { revolution, there were budget savings by printing HVS } \\
\text { paper. The manual is more expensive and } \\
\text { when it is revolutionary, it is very, very } \\
\text { much cheaper in comparison. For example in } 2020 \text {, } \\
\text { the City of Tegal until December only printed } \\
22,220 \text { Family Cards, and it usually reaches } \\
35,000 \text { in a year for all documents. Manually, the } \\
\text { budget is approximately Rp; } 175,000,000 \text {, digitally } \\
\text { only Rp; } 35,000 \text { because the price of a piece of HVS } \\
\text { paper is only } 1 \text { rupiah. This applies to the Population } \\
\text { and Civil Registration Agency in Indonesia. }\end{array}$ \\
\hline $\begin{array}{l}\text { How long does it take to } \\
\text { update the data independently } \\
\text { for validation? }\end{array}$ & Based on SOP 1 x 24 hours. \\
\hline
\end{tabular}


TABLE III. RESULTS OF THE INTERVIEW WITH THE GRAB EXPRESS COMPANY

\begin{tabular}{|c|c|}
\hline $\begin{array}{l}\text { In your opinion, how } \\
\text { important are public services, } \\
\text { especially services from Grab } \\
\text { itself, during the Pandemic } \\
\text { era? }\end{array}$ & $\begin{array}{l}\text { Public services must be maximized } \\
\text { regardless of the conditions. Grab wants to } \\
\text { help the government in digitizing, therefore } \\
\text { partners in sending documents, especially } \\
\text { regarding the Jakwir Cetem application } \\
\text { service in Tegal City. }\end{array}$ \\
\hline $\begin{array}{l}\text { Through a partnership } \\
\text { program with the Population } \\
\text { and Civil Registration Agency } \\
\text { of Tegal City in the service of } \\
\text { Jakwir Cetem, In your } \\
\text { opinion, has Jakwir Catem } \\
\text { been effective? }\end{array}$ & $\begin{array}{l}\text { Of course, because makes it easier for } \\
\text { people to get services in population } \\
\text { documents instead of having to queue and } \\
\text { spend a lot of time. }\end{array}$ \\
\hline $\begin{array}{l}\text { What are the obstacles faced } \\
\text { by Grab Express partners } \\
\text { during the Pandemic era? }\end{array}$ & $\begin{array}{l}\text { So far so good, there have been no } \\
\text { obstacles hindering our partnership with the } \\
\text { Population and Civil Registration Agency. } \\
\text { If there is, we will solve it as soon as } \\
\text { possible. }\end{array}$ \\
\hline $\begin{array}{l}\text { How did it start that Grab } \\
\text { decided to partner with the } \\
\text { Population and Civil } \\
\text { Registration Agency in this } \\
\text { service? }\end{array}$ & $\begin{array}{l}\text { Overall this idea came from the } \\
\text { government, and we got up to help them in } \\
\text { providing technology- based services to } \\
\text { make it easier for society. }\end{array}$ \\
\hline $\begin{array}{l}\text { How do the people of Tegal } \\
\text { City respond to this } \\
\text { partnership program? }\end{array}$ & $\begin{array}{l}\text { They really welcome this partnership } \\
\text { program especially in the midst of a } \\
\text { pandemic because the community feels it } \\
\text { is facilitated. }\end{array}$ \\
\hline $\begin{array}{l}\text { What benefits did Grab } \\
\text { Express get after the Jakwir } \\
\text { Cetem program was running, } \\
\text { and even made achievements? }\end{array}$ & $\begin{array}{l}\text { That is, many drivers are helped financially } \\
\text { by delivering documents, due to the } \\
\text { pandemic era, many orders are very quiet. } \\
\text { Also, the level of trust of the people } \\
\text { of Tegal City in Grab tends to increase. }\end{array}$ \\
\hline $\begin{array}{l}\text { In your opinion, can the } \\
\text { answers to the previous } \\
\text { questions be used as an } \\
\text { exemplary alternative solution } \\
\text { in public services for other } \\
\text { regions? }\end{array}$ & $\begin{array}{l}\text { This is very feasible and appropriate, } \\
\text { because this innovation will create a high } \\
\text { demand from the community to local } \\
\text { governments }\end{array}$ \\
\hline $\begin{array}{l}\text { What interesting things made } \\
\text { Tegal City's Population and } \\
\text { Civil Registration Agency } \\
\text { finally choose to partner with } \\
\text { Grab Express? }\end{array}$ & $\begin{array}{l}\text { It's about Grab having amazing features. } \\
\text { specifically in Tegal City, Grab has } \\
\text { employee and developer representatives } \\
\text { and service prices are able to compete with } \\
\text { various promo features available. In this } \\
\text { SOP, the grab driver has also gone through } \\
\text { the required training. }\end{array}$ \\
\hline $\begin{array}{l}\text { In the future, is Grab Express } \\
\text { interested in running other } \\
\text { partnership programs in public } \\
\text { services? }\end{array}$ & $\begin{array}{l}\text { Yes, we are interested and are in the } \\
\text { process of partnership with other agencies, } \\
\text { especially in Tegal City to support towards } \\
\text { a smart city. }\end{array}$ \\
\hline
\end{tabular}

B. Data Analysis of Jakwir Cetem Application Service Survey with Delone and McLean Model

The results of our survey analysis can find out how the public's perception of the Tegal City Population and Civil Registration Agency service to the Jakwir Cetem application service. We created a questionnaire using survey data collection techniques for all people in Tegal City and obtained 59 respondents. It is dominated by the Student / Student profession at $50.8 \%$. While other respondents work in the private sector $(18.6 \%)$, housewives $(15.3 \%)$, entrepreneurs (5.1\%), civil servants (3.4\%), BUMN / BUMD (1.7\%), drivers $(1.7 \%)$, some even work odd jobs (1.7\%). This analysis categorizes the respondents as non-users of the Jakwir Cetem application service and users of the Jakwir Cetem application service. This allows us to get another point of view from nonusers of the Jakwir Cetem application regarding how the accessibility is used for the services provided by the Population and Civil Registration Agency of Tegal City without using the Jakwir Cetem application is compared to the user's perspective. Then we analysed the aspects that must be improved by the Population and Civil Registration Agency of Tegal City on the implementation of Jakwir Cetem such as increasing socialization or promotion to reach a wider range of benefits for the success of this service product goal.

Based on the survey results, there are $57.6 \%$ of respondents who are not users and $42.4 \%$ of users of the Jakwir Cetem application service. The first reason for non- users of this application service is due to the lack of knowledge and understanding of the use and ease of access offered by the Tegal City Population and Civil Registration Agency, so there is a need to be guided by holding wider socialization. Meanwhile, the service system used by non- users based on the survey results reached $83.3 \%$ preferring to visit the Tegal City Population and Civil Registration Agency office and 25\% choose to contact the Tegal City Population and Civil Registration Agency service contact. So, it can be interpreted that the offer of service features provided by the Tegal City Population and Civil Registration Agency has not been fully able to attract the attention of the public. They are still fixated on accessing conventional services. However, the interest of the non-user community has reached $82.1 \%$, meaning that there is a great desire for non-users to be able to take advantage of and use the Jakwir Cetem application service in the future after getting a little information from the results of filling out the survey questionnaire we made.

The results of the survey of respondents' responses to the Tegal City Population and Civil Registration Agency service in using the Jakwir Cetem application service were analysed as research objects about user satisfaction with the service quality of the Tegal City Population and Civil Registration Agency and the Jakwir Cetem application. We analyse user satisfaction using the DeLone and Mclean information system success model with qualitative research methods.

\section{Quality of Information Systems}

Based on the diagram image of the survey results, the service quality information of the Jakwir Cetem application can be reviewed by evaluating each indicator, such as:

\section{1) Completeness:}

All the features provided are complete according to my needs (Completenees)
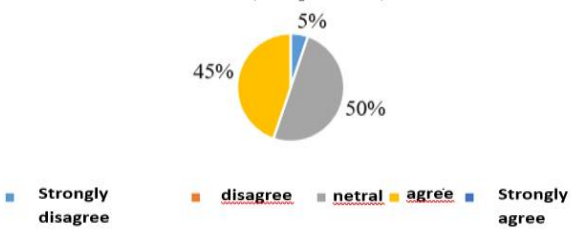

Fig. 2. Completeness survey results. 
Based on the survey results (figure 2) regarding the indicators of completeness of the Jakwir Cetem application service features, the majority of users have a neutral view of $50 \%$. There are no users who disagree with the completeness of the features available, and $45 \%$ of users have agreed. This means that the features in the Jakwir Cetem application system are deemed complete to be accessible and by the needs of the people of Tegal City.

\section{2) Precision:}

The information is accurate to me (Precision)

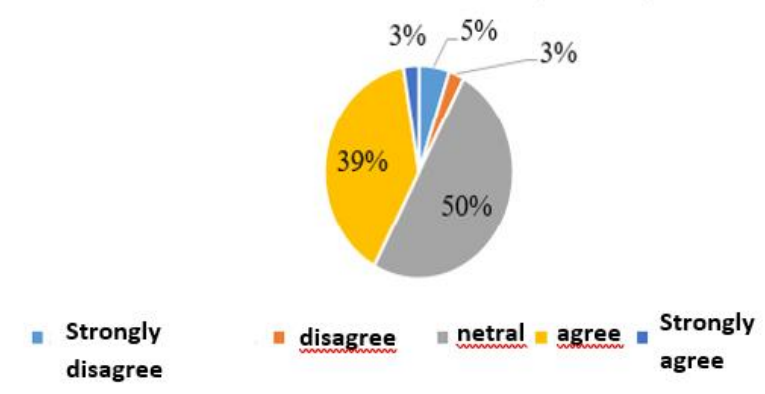

Fig. 3. Precision survey results.

Based on accurate data indicators and information provided by the Jakwir Cetem service system (figure 3), most of the people of Tegal City have a neutral perception as much as $50 \%$ of the total 59 respondents. However, there is still a perception of strongly disagree at $5 \%$ and a perception of disagree at $3 \%$. It is possible that the public still knows the accuracy of the Jakwir Cetem Application service system in using this service.

\section{3) Reliability:}

The available features are reliable according to my needs (Reliability)

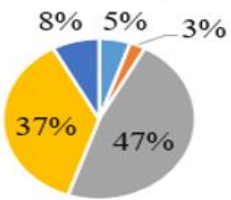

= Strongly

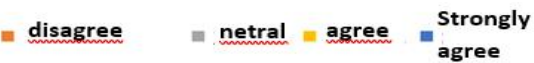

Fig. 4. Reliability survey results

Based on the reliability indicator of the Jakwir Cetem application service system (figure 4), it is still dominated by user neutral perceptions of $47 \%$, and there are $37 \%$ of users who choose to agree with the available and reliable features according to community needs. Tegal City. There are still users who strongly disagree as much as $5 \%$ and disagree as much as $3 \%$. So that there are still those who doubt the reliability of the features provided in the Jakwir Cetem Application.

\section{4) Format of output:}

The data / information that I use can be used in other media (format of output)

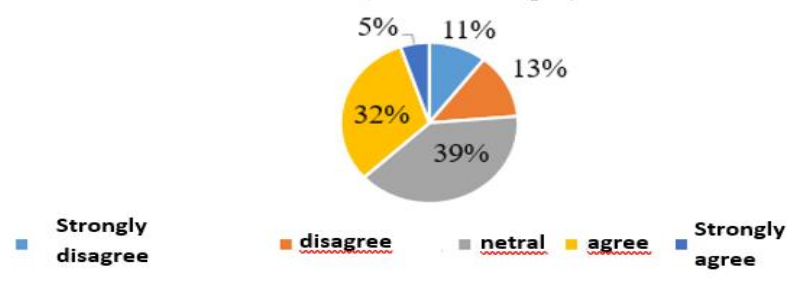

Fig. 5. Format of output survey results

From the survey results, the output indicators of users of the Jakwir Cetem Application service (figure 5) are more dominant in being neutral towards service output and accessibility, so that they can connect with other media. In fact, $11 \%$ of users strongly disagree and $13 \%$ of users disagree, although there are still some who agree and strongly agree. This means that the service output in the form of data and information is still in service quality.

\section{System Quality}

Based on the diagram image of the survey results, the service quality information of the Jakwir Cetem application can be reviewed by evaluating each indicator, such as:

\section{1) System flexibility:}

The data / information that I use can be used in other media (format of output)

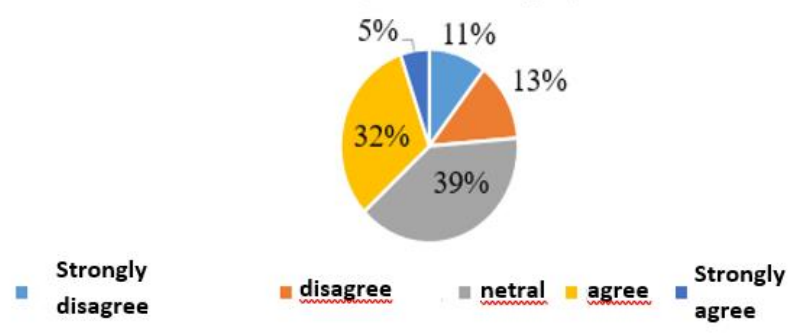

Fig. 6. System flexibility survey results.

Based on the survey results (figure 6), the indicator for the flexibility of the Jakwir Cetem system is still dominated by user neutral perceptions. Apart from a few users being quite satisfied with agreeing, some users disagree strongly about the flexibility of the system. This can be seen from several criticisms that there are users who have difficulty changing some of the input data. So that this can be a quality improvement factor for the flexibility of this application service system. 


\section{2) System integration:}

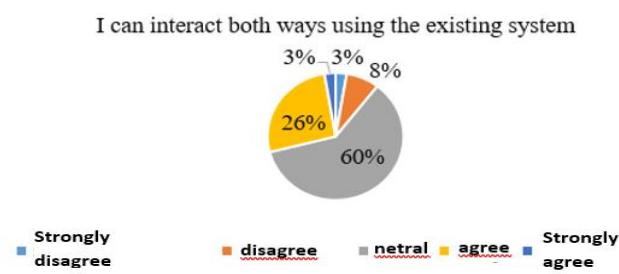

Fig. 7. System integration survey results.

According to the results of the system integration indicator survey (figure 7), users are expected to get integrated services in the Jakwir Cetem application. If there is a two-way interaction with service providers not only by relying on bots, then system integration can be achieved because all components are involved in the system. User neutral perceptions about system integration are still the majority. Some agree and even strongly agree, but the differences are quite contrasting, especially there are perceptions of disagreeing and strongly disagreeing. The quality of system integration is not sufficient for users of this application.

3) Time to respond:

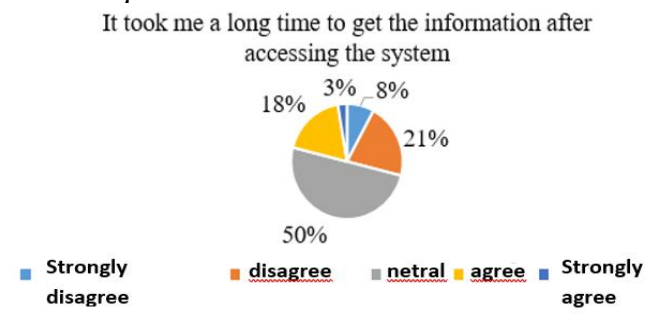

Fig. 8. Time to respond survey results.

According to the results of the response time indicator survey (figure 8), users stated that they were normal or neutral towards the time spent accessing the Jakwir Cetem application system. Some others choose it does not take long, but some users feel the long access time to get service responses from this application. This means that users do not feel that the Jakwir Cetem application service can make time to get services efficient.

\section{4) Fixes errors:}

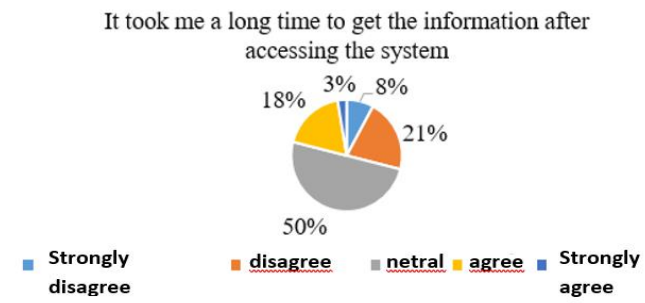

Based on the survey results regarding the error fixes indicator (figure 9), many users have a neutral perception of the failure of the Jakwir Cetem application system. It could be that users are using the app only occasionally, so they do not experience much system failure experience.

5) Convenience of access:

It took me a long time to get the information after accessing the system

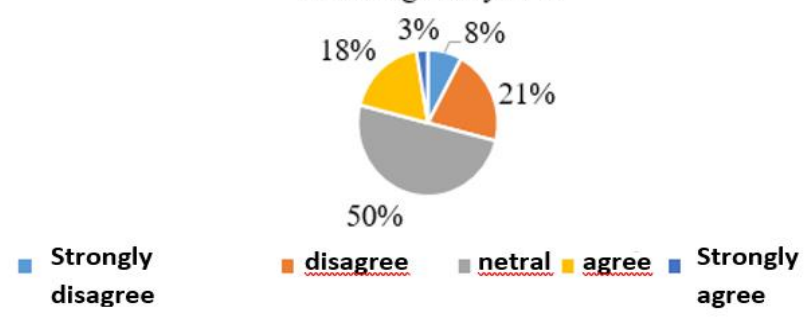

Fig. 10. Convenience of access survey results.

Based on the survey results regarding the convenience of access indicators (figure 10), many users choose neutral, meaning that they are still normal in accepting the security that has been given to the Jakwir Cetem application service. Other users feel agree, strongly agree, and also who feel strongly disagree.

\section{6) Language:}

The system language used is easy to understand (language)
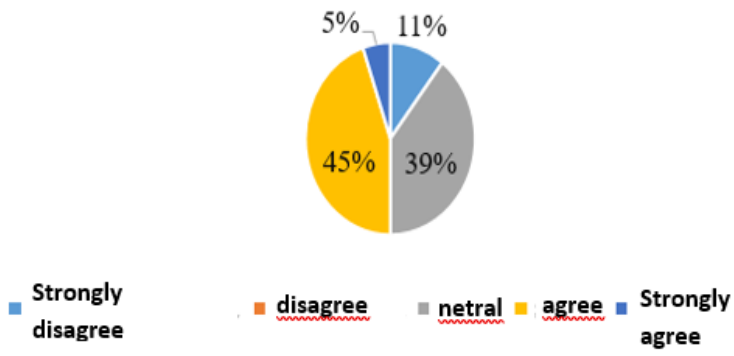

Fig. 11. Language survey results.

Based on the survey results, $45 \%$ of Jakwir Cetem application service users really understand the language used, $39 \%$ express neutrality, 5\% strongly agree, and $11 \%$ strongly disagree (figure 11). If users are accustomed to using this application service, it is certainly no longer difficult to know and understand the language, and it is different from ordinary people who are still confused about accessing these services.

7) Service quality: Based on the diagram image of the survey results on the service quality of the Jakwir Cetem application, it can be reviewed by evaluating each indicato, such as:

Fig. 9. Fixes errors survey results. 


\section{8) Assurance:}

I feel safe in accessing or sending data through the system

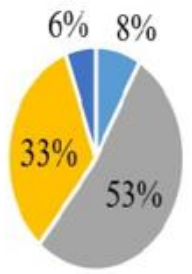

$$
\begin{aligned}
& \text { Strongly } \\
& \text { disagree }
\end{aligned} \quad \text { disagree } \quad \| \text { netral }=\text { agree }=\begin{aligned}
& \text { Strongly } \\
& \text { agree }
\end{aligned}
$$

Fig. 12. Assurance survey results.

Based on the survey results on the quality assurance indicators provided by the Jakwir Cetem application system (figure 12), it is deemed sufficient to provide trust from users. They can access or send data through the system securely. There are still users who feel very insecure. Therefore, the quality assurance system still does not get the full trust of its users.

\section{9) Empathy:}

I feel safe in accessing or sending data through the system
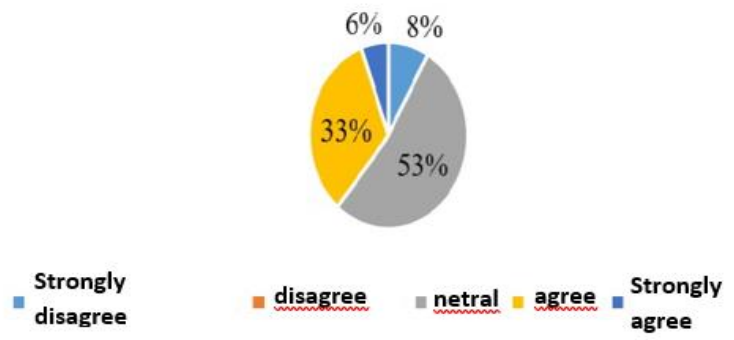

Fig. 13. Empathy survey results.

According to the survey results on the empathy indicator (figure 13), users still feel normal, and some argue that they have been given good feedback from service providers. This is probably due to the lack of socialization for all people in Tegal City.

10) Responsiveness:

I feel safe in accessing or sending data through the system
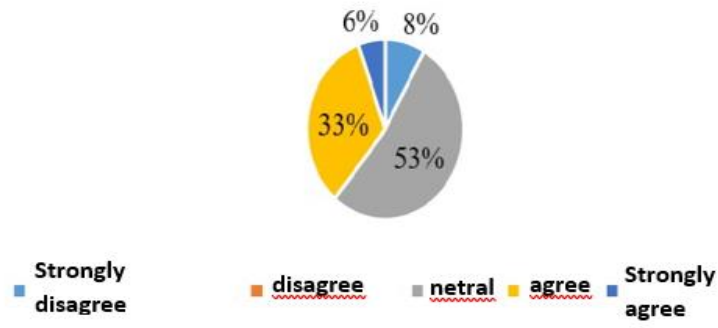

Fig. 14. Responsiveness survey results.
Based on the survey results on the quality indicator of the system response to the actions taken by Jakwir Cetem users (figure 14), it is considered sufficient because most users state neutrality and agree, although a few of these users strongly disagree. This means that there are still a handful of users who have not been responded well to by the Jakwir Cetem application system.

E. Use

Based on the diagram image of the survey results on the use of the Jakwir Cetem application service, it can be reviewed by evaluating each indicator, such as:

1) Daily used time:

I feel safe in accessing or sending data through the system

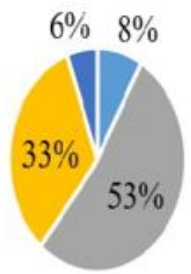

$$
\begin{aligned}
& \text { Strongly } \\
& \text { disagree }
\end{aligned} \text { disagree } \| \text { netral } \| \text { agree } \| \begin{aligned}
& \text { Strongly } \\
& \text { agree }
\end{aligned}
$$

Fig. 15. Daily used time survey results.

Based on the survey results of the daily time usage indicator (figure 15), most users of the Jakwir Cetem application rarely use this application every day. However, as many as $34 \%$ of users access it sometimes and some are often as much as $20 \%$ of the total number of respondents.

2) Frequency of use:

How often did you access the system while being a user?

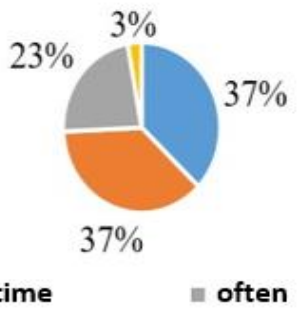

" Very often

Fig. 16. Frecuency of use survey results.

Based on the results of the survey on the frequency of use indicator (figure 16), users of the Jakwir Cetem application still say that they rarely access the system as long as they are users, but the level of coolness increases than the daily used time indicator. This means that these users only access applications when they need essential services, while for other service needs, they can use other media. 


\section{F. User Satisfaction}

Based on the diagram image of the survey results on user satisfaction of the Jakwir Cetem application service, it can be reviewed by evaluating each indicator, such as:

\section{1) Information satisfaction:}

How often did you access the system while being a user?

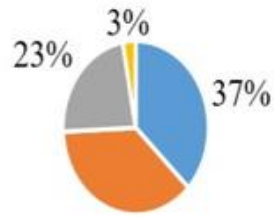

$37 \%$

$$
\text { |1 rarely = sometime } \quad \text { || often } \quad \text { Very often }
$$

Fig. 17. Information satisfaction survey results.

Based on the results of the survey on the indicators of information satisfaction (figure 17), the level of satisfaction with the data and information provided by the Jakwir Cetem application is still low because more users say they are quite satisfied and even some say they are very dissatisfied when getting data and information in services. Therefore, it is necessary to increase satisfaction in providing all information related to population data to the people of Tegal City.

\section{2) Complete satisfaction:}

How often did you access the system while being a user?

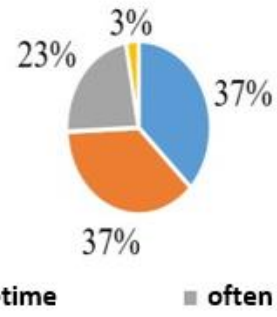

" Very often

Fig. 18. Complete satisfaction survey results.

Based on the survey results on the overall satisfaction indicators (figure 18), as well as the level of satisfaction with data and information, the level of satisfaction with all the features provided is still low, seeing the statements of users who are still quite satisfied differ greatly in the level of satisfaction below.

\section{G. Net Benefit}

Based on the diagram image of the survey results on the net obtained on the Jakwir Cetem application service, it can be reviewed by evaluating each indicator, such as:

\section{1) Speed of acomplishing task:}

I can receive services faster using the system
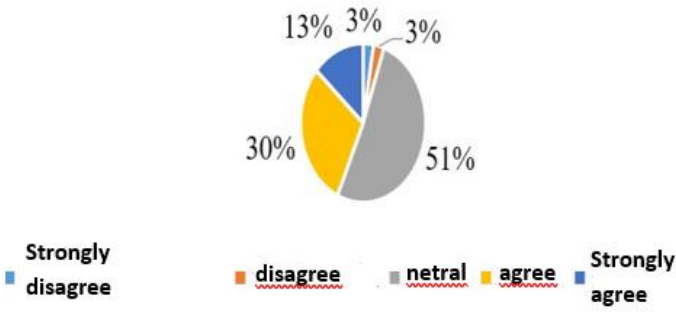

Fig. 19. Speed of acomplishing task survey results.

Based on the survey results on the speed of accomplishing tasks (figure 19), the majority of users of the Jakwir Cetem application have a neutral perception of the speed of system performance. This means that it is in accordance with its function, this application supports the speed of providing service to customers. However, there are still a small number of people who strongly disagree and there are also those who disagree regarding the speed with which the system meets community needs.

\section{2) Job performance:}

More effective service by using the system
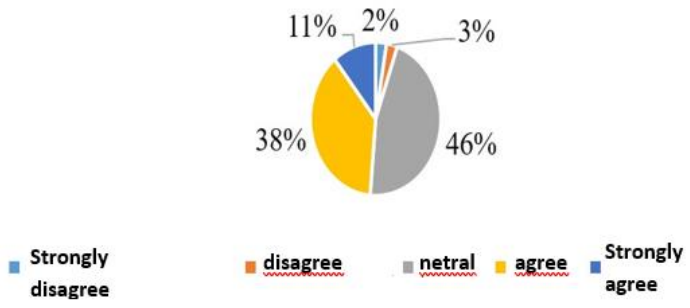

Fig. 20. Job performance survey results.

Based on the survey results on performance indicators (figure 20), users of the Jakwir Cetem application have more neutral perceptions of the better service performance of the Tegal City Population and Civil Registration Agency Service by using the system. This means that this application system is actually needed by customers.

\section{3) Effectiveness:}

Better service performance using the system

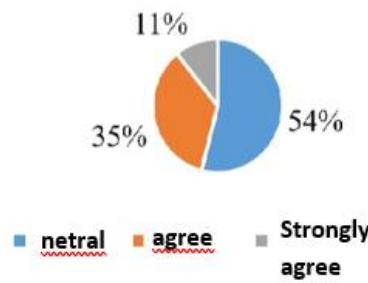

Fig. 21. Effectiveness survey results. 
Based on the survey results on the effectiveness indicator (figure 21), the majority of users have a neutral perception of $46 \%$, the perception of agreeing is $38 \%$, the perception of strongly agreeing is $11 \%$, the perception of disagreeing is $3 \%$, and the perception of strongly disagreeing is as much as $2 \%$ of the more effective access to Service Services. Population and Civil Registration Agency of Tegal City using the Jakwir Cetem application system. This means that there is still improvement, not only from improving system components but from other aspects such as system publication.

\section{4) Ease of job}

Better service performance using the system

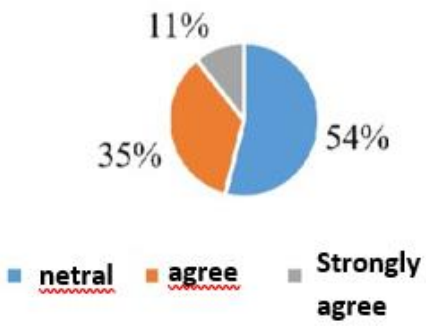

Fig. 22. Ease of job survey results.

Based on the survey results on the ease of job indicators (figure 22), more users have the perception of agreeing with the ease of accessing Population and Civil Registration Agency of Tegal City services by using the Jakwir Cetem application. Then the goal of service products has been achieved so that people are no longer fixated on conventional services but can also easily use this system.

5) Usefullness in work:

The system is very useful in meeting my needs

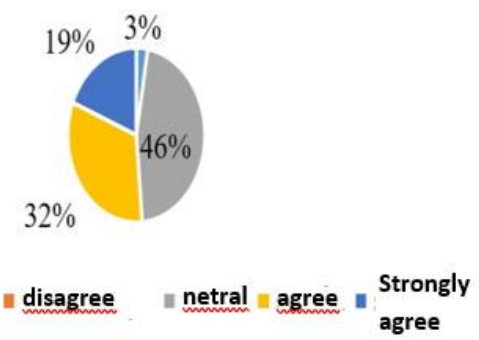

Fig. 23. Usefullness in work survey results.

Based on the results of the survey on the usability indicators in the work of most users (figure 23), there are similarities in the neutral and agreed perceptions of the majority of users of the Jakwir Cetem application regarding its usefulness in meeting needs. So, the system can be said to be quite successful but not yet optimal in serving the needs of users because there are still users who have a perception of strongly disagreeing as much as $3 \%$.

\section{CONCLUSION}

The existing service process must be able to uphold professional values, the quality-of-service products must be maintained, and the cost and completion time are in accordance with the standards regardless of the era that is being faced including in the midst of an ongoing virus. Therefore, the Tegal City Population and Civil Registration Agency has made a new breakthrough, namely a service system in partnership with Grab Express in the Jakwir Cetem application which is able to make it easier for the people of Tegal City to manage all population data including free document delivery. The results of survey analysis using the DeLone and McLean's model theory, we can find out people's perceptions about the Tegal City Population and Civil Registration Agency services on the Jakwir Cetem application service. We created a questionnaire using survey data collection techniques for all people in Tegal City so that it obtained 59 respondents. The majority of users of the Jakwir Cetem application as customers of the Tegal City Population and Civil Registration Agency services electronically have a fairly good perception of the services provided by this application. If the implementation of public services by the Population and Civil Registration Agency of Tegal City can better and more sustainably meet community expectations, then the service can be said to be successful. The quality-of-service products from the Tegal City Population and Civil Registration Agency really needs to be optimized, especially the Jakwir Cetem application service as a current service innovation.

\section{REFERENCES}

[1] L. Oktaviana, "Strategi Peningkatan Pelayanan Perekaman E-KTP Melalui Pelayanan Jemput Bola Pada Dinas Kependudukan Dan Pencatatan Sipil Kota Surabaya,” Publika, vol. 6, no. 2, 2018.

[2] T. Soemartono and S. Hendrastuti, Administrasi kependudukan berbasis registrasi. Yayasan Bina Profesi Mandiri, 2011.

[3] T.L. Nguyên, National identification systems (Doctoral dissertation, Massachusetts Institute of Technology), 2003.

[4] P.H. Saputro, D. Budiyanto and J. Santoso, "Model DeLone and McLean untuk mengukur kesuksesan e-government Kota Pekalongan,' Scientific Journal of Informatics, vol. 2, no. 1, pp. 1-8, 2015

[5] P. Seddon and M.Y. Kiew, "A partial test and development of DeLone and McLean's model of IS success," Australasian Journal of Information Systems, vol. 4, no. (1), 1996.

[6] J. Iivari, Information systems as a design science. In Information systems development (pp. 15-27). Boston, MA: Springer, 2005.

[7] W.H. DeLone and E.R. McLean, "The DeLone and McLean model of information systems success: a ten-year update," Journal of management information systems, vol. 19, no. 4, pp. 9-30, 2003

[8] F.D. Davis, "Perceived usefulness, perceived ease of use, and user acceptance of information technology," MIS Q, vol. 13, pp. 319-339, 1989 